\title{
THE NUTRITIONAL REQUIREMENTS FOR NITROGEN BALANCE IN SURGICAL PATIENTS DURING THE EARLY POSTOPERATIVE PERIOD ${ }^{1}$
}

By CECILIA RIEGEL, C. EVERETT KOOP, JOHN DREW, L. W. STEVENS, AND J. E. RHOADS

\begin{abstract}
WITH THE TECHNICAL ASSISTANCE OF LOUISA BULLITT, DOROTHY BARRUS, ROZANNE P. GRIGGER, MARIE BARNES, ANNE BARNHART, JANET BOGER, FRANCES BOWEN, EINA GOULDING, AND ELEANOR MCGINLEY

(From the Harrison Department of Surgical Research, Schools of Medicine, University of Pennsylvania and the Surgical Clinic of the Hospital of the University of Pennsylvania, Philadelphia
\end{abstract}

(Received for publication. February 25, 1946)

The role of protein nutrition in the convalescence of surgical patients has been emphasized by many authors during the past 15 years, and much of this work has recently been ably reviewed by Lund (1). The observations of Cuthbertson (2), confirmed by Howard and his co-workers (3), that fractures of long bones resulted in a marked negative nitrogen balance which could not be overcome by substantial increases in the protein intake, raised certain questions regarding the possible effects on nitrogen requirements and nitrogen balance of extensive surgical operations. It seemed important to know how soon after operation a positive nitrogen balance could be re-established, and what levels of nitrogen and caloric intake would be required to accomplish this.

Many of the previous concepts of the protein nutrition of surgical patients have been based on changes which were found in the serum protein concentration at different periods. It is generally acknowledged that the use of such data may lead to erroneous conclusions, but they have continued to be used by many investigators chiefly because of the difficulties in carrying out the more informing balance studies. In this project, additional technical aid made it possible for us to carry out both types of study. Our results indicate that the serum protein concentration may, at times, increase in spite of a negative nitrogen balance during the period of study.

It has also been possible to compare the effectiveness of whole protein with various preparations

1 The work described in this paper was done under a contract, recommended by the Committee on Medical Research between the Office of Scientific Research and Development and the University of Pennsylvania. of hydrolyzed protein in the maintenance of the patient's nutrition after an operation on the gastrointestinal tract.

\section{PROCEDURE}

In selecting patients, we gave preference to young adult males, but we did not limit the study to this group. The patients selected had usually undergone an extensive surgical operation, and usually one which interfered, at least to some extent, with the ability to eat. Thus, preference was given to patients who had had a gastric resection, and to neurosurgical patients who had had a craniotomy or craniectomy. The latter group will be considered in more detail in a separate paper, but the entire series is presented in Table I.

In the gastric cases, Abbott-Rawson tubes were frequently placed at operation either according to the orojejunal method of Stengel and Ravdin (4) or according to the gastro-jejunal method of Bisgard (5). In the craniotomy cases, Levine tubes were often passed into the stomach. Some patients in both groups were fed by mouth.

The various types of feeding used may be listed as follows :

1. Food from a metabolic kitchen, either in the form of a liquid, soft or full hospital diet.

2. Amigen (enzymatic digest of casein and pancreas). ${ }^{2}$

3. Amigen and hospital diet.

4. Lactalbumin hydrolysate. ${ }^{3}$

5. Gastrostomy mixture prepared in the following proportions :

Skim milk ............ $500 \mathrm{ml}$.

Skim milk powder ...... 50 grams

Cottage cheese ......... 50 grams

Soybean flour .......... 50 grams

Egg $\ldots \ldots \ldots \ldots \ldots \ldots \ldots, 1$

\section{Preparation of feedings.}

The desired amount of Amigen was dissolved in water and either glucose, starch or Dextrimaltose added to make

2 Amigen powder (Mead Johnson \& Co.).

3 Wyeth and Co. 
up the predetermined number of calories. In some patients the Amigen was given in water, and additional calories were furnished by a glucose solution given intravenously. The volume of solution given by mouth or tube was approximately $200 \mathrm{ml}$. at a single feeding, and the frequency of feeding was varied so as to provide the total amount of nitrogen and the calories desired in any 24-hour period. Usually $200 \mathrm{ml}$. were given every 2 to 3 hours. Lactalbumin hydrolysate was administered in the same manner as Amigen. The gastrostomy mixture was prepared in the laboratory, and carbohydrate was added to provide the desired number of calories.

In the early part of the work the patients were studied for 10 days postoperatively. It became apparent that the usual negative nitrogen balance found following operation became a positive balance as the patients began to eat larger quantities of food. In the latter part of our work, therefore, we limited our nitrogen balance studies to the first 5 days of the postoperative period.

\section{Methods of administration.}

When food was given by mouth, it was offered at regular hours, and records were kept of the food actually ingested. When the patient was on a constant intake, the portions not eaten at the regular meal hour, or equivalent substitutes, were offered between meals.

When the patient was fed by tube, the feeding was administered by the drip method. Small portions (usually $200 \mathrm{ml}$.) were given at intervals of 2 to 3 hours throughout the day. When the gastrostomy mixture was too thick to run by gravity through small tubes, the feedings were injected slowly into the tube by syringe.

\section{Collection of specimens.}

All urine was collected under toluene for 24-hour periods throughout the period of study, and sent to the laboratory where volume measurements were made.

Feces were collected in many, but not in all cases; but when they were, the patient was given carmine by mouth at the beginning of the study and at the end of 5 days. Feces were collected as 24 -hour specimens from the day of appearance of the first carmine up to and including the day of appearance of the second carmine.

Vomitus was collected and analyzed for total nitrogen. Material obtained by suction drainage was carefully collected and analyzed.

\section{Methods of analysis.}

All total nitrogen determinations were done by a semimicro Kjeldahl method (6a and b) and nonprotein nitrogen by a colorimetric method using Nessler's reagent (7).

Samples of Amigen, of lactalbumin hydrolysate, and of the gastrostomy mixture were analyzed for nitrogen. Food furnished as "Hospital Diet" was not analyzed in the laboratory, but values as given in standard diet tables were used (8a and $b)$. Urine was usually diluted $1: 50$ or $1: 100$, plasma $1: 10$, and appropriate samples taken for analysis. Feces were thoroughly mixed by mechanical stirring in acidified water, and an appropriate sample taken for analysis.

Hematocrit readings were determined in SanfordMagath tubes, using heparin as the anticoagulant.

\section{RESULTS}

\section{Nitrogen balance.}

Table I shows the results of studies on 55 patients fed by mouth or tube. The results are arranged in order of an increasing nitrogen intake. It is evident that :

1. Thirty-seven (67 per cent) of the 55 patients were in negative nitrogen balance for the first 5 postoperative days ; 5 were in equilibrium, ${ }^{4}$ and 13 were in positive nitrogen balance.

2. Of 18 in equilibrium or in positive nitrogen balance, 12 fell in the group receiving 0.3 gram of nitrogen per kgm., and 30 calories per $\mathrm{kgm}$. or more daily.

3. Of 18 getting 0.3 gram of nitrogen or over, 12 were in positive nitrogen balance; 6 were in negative nitrogen balance. Of these 6,3 were on low caloric intakes.

\section{Type of operation.}

Most of the patients studied fell into two groups, (1) gastric and (2) cranial operation. Dividing the patients into these 2 groups failed to show any gross difference in the results of feeding on nitrogen balance; i.e., in both groups, most of the patients who were in balance received 0.3 gram of nitrogen and 30 calories per $\mathrm{kgm}$. daily, or over.

\section{Age and sex.}

No correlation was found between age or sex of patients and their ability to attain nitrogen equilibrium with comparable nitrogen and caloric intake.

\section{Nitrogen losses in feces.}

There was considerable variation between patients in the amount of nitrogen excreted in the feces. Table II gives figures for the range of excretion and average of a number of patients grouped according to the method of feeding. Those patients who were fed by tube into the jejunum showed the greatest average loss of ni-

4 If the patient had a daily average nitrogen balance of -1.0 to 0.0 , he was considered to be in nitrogen equilibrium. 
TABLE I

\begin{tabular}{|c|c|c|c|c|c|c|c|c|c|c|c|c|}
\hline \multirow[b]{2}{*}{ Patient } & \multirow[b]{2}{*}{ Operation } & \multirow[b]{2}{*}{ Diet } & \multicolumn{3}{|c|}{$\begin{array}{c}\text { Nitrogen } \\
\text { per intake }\end{array}$} & \multicolumn{5}{|c|}{$\begin{array}{l}\text { Nitrogen output } \\
5 \text { day period }\end{array}$} & \multicolumn{2}{|c|}{$\begin{array}{c}\text { Nitrogen } \\
\text { balance }\end{array}$} \\
\hline & & & $\begin{array}{l}\text { N per } \\
\text { kgm. } \\
\text { daily }\end{array}$ & $\begin{array}{c}\text { Cal. } \\
\text { per } \\
\text { kgm. } \\
\text { per } \\
\text { day }\end{array}$ & $\begin{array}{l}\text { Total } \\
\text { N } 5 \\
\text { days }\end{array}$ & Urine & Feces & $\begin{array}{c}\text { Drain- } \\
\text { age }\end{array}$ & $\begin{array}{c}\text { Vomi- } \\
\text { tus }\end{array}$ & Total & $\begin{array}{l}\text { Total } \\
5 \text { days }\end{array}$ & $\begin{array}{l}\text { Daily } \\
\text { aver. }\end{array}$ \\
\hline $\begin{array}{l}\text { Co. } \\
\text { Ca. } \\
\text { Fa. } \\
\text { Fri. } \\
\text { Fe. } \\
\text { Ha. } \\
\text { Le. } \\
\text { Ri. } \\
\text { Or. } \\
\text { Ro. } \\
\text { Ei. } \\
\text { Cot. } \\
\text { Wa. } \\
\text { Sm. } \\
\text { Ho. } \\
\text { Jo. } \\
\text { Th. } \\
\text { Rob. } \\
\text { Lu. } \\
\text { Wo. } \\
\text { Ham. } \\
\text { Fes. } \\
\text { Wi. } \\
\text { Bu. } \\
\text { Brad. } \\
\text { Ma. } \\
\text { De. } \\
\text { War. } \\
\text { Ga.8 } \\
\text { Mc. } \\
\text { Mar. } \\
\text { Len. } \\
\text { Fu. } \\
\text { Th.T. } \\
\text { Be. } \\
\text { Sc. } \\
\text { Po. } \\
\text { Do. } \\
\text { Fo. } \\
\text { Sm.E. } \\
\text { Br. } \\
\text { Cl. } \\
\text { Cu. } \\
\text { Ga. } \\
\text { Ch. } \\
\text { Ba. } \\
\text { To. } \\
\text { Ar. } \\
\text { Smi. } \\
\text { Bra. } \\
\text { St. } \\
\text { Ro. } \\
\text { No. } \\
\text { Lo. } \\
\text { Bru. }\end{array}$ & $\begin{array}{l}\text { Rankin resect. } \\
\text { Gastric resect. } \\
\text { Gastric resect. } \\
\text { Expl. lap. } \\
\text { Gastro-enterost. } \\
\text { Gastric resect. } \\
\text { Gastric resect. } \\
\text { Craniotomy } \\
\text { Gastric resect. } \\
\text { Gastric resect. } \\
\text { Gastric resect. } \\
\text { Craniotomy } \\
\text { Gastric resect. } \\
\text { Craniotomy } \\
\text { Craniotomy } \\
\text { Craniotomy } \\
\text { Gastric resect. } \\
\text { Craniotomy } \\
\text { Thyroidectomy } \\
\text { Craniotomy } \\
\text { Expl. lapar. } \\
\text { Craniectomy } \\
\text { Craniotomy } \\
\text { Craniotomy } \\
\text { Gastric resect. } \\
\text { Gastric resect. } \\
\text { Gastric resect. } \\
\text { Expl. lapar. } \\
\text { Gastric resect. } \\
\text { Gastro-enterost. } \\
\text { Gastric resect. } \\
\text { Craniotomy } \\
\text { Craniotomy } \\
\text { Craniotomy } \\
\text { Craniotomy } \\
\text { Ca. esophagus } \\
\text { Gastrostomy } \\
\text { Pit. explor. } \\
\text { Gastric resect. } \\
\text { Craniotomy. } \\
\text { Cranioplasty } \\
\text { Gastric resect. } \\
\text { Craniotomy } \\
\text { Craniotomy } \\
\text { Gastro-enterost. } \\
\text { Gastric resect. } \\
\text { Gastro-enterost. } \\
\text { Gastric resect. } \\
\text { Gastrectomy } \\
\text { Gastrectomy } \\
\text { Gastro-enterost. } \\
\text { Expl. lapar. } \\
\text { Craniotomy } \\
\text { Gastric resect. } \\
\text { Gastro-enterost. }\end{array}$ & $\begin{array}{l}\text { Glucose+hosp. } \\
\text { Glucose+hosp. } \\
\text { Hospital } \\
\text { Glucose+hosp. } \\
\text { Hospital } \\
\text { Glucose+hosp. } \\
\text { Hospital } \\
\text { Hospital } \\
\text { Gastrostomy mix. } \\
\text { Hospital } \\
\text { Hospital } \\
\text { Hospital } \\
\text { Hospital } \\
\text { Hospital } \\
\text { Gastrostomy mix. } \\
\text { Hospital } \\
\text { Hospital } \\
\text { Hospital } \\
\text { Hospital } \\
\text { Hospital } \\
\text { Hospital } \\
\text { Glucose+hosp. } \\
\text { Hospital } \\
\text { P. K. gastrost. } \\
\text { Hospital } \\
\text { Hospital } \\
\text { Hospital } \\
\text { Amigen+hosp. } \\
\text { Amigen } \\
\text { Amigen } \\
\text { Hospital } \\
\text { P. K. gastrost. } \\
\text { Gastrostomy mix. } \\
\text { Amigen+hosp. } \\
\text { Amigen } \\
\text { Gastrostomy mix. } \\
\text { Gastrostomy mix. } \\
\text { Amigen+hosp. } \\
\text { Lactalbumin } \\
\text { Lactalbumin } \\
\text { Amigen+ hosp. } \\
\text { Amigen } \\
\text { Amigen } \\
\text { Amigen } \\
\text { Lactalbumin } \\
\text { Lactalbumin } \\
\text { Gastrostomy mix. } \\
\text { Amigen } \\
\text { Gastrostomy mix. } \\
\text { Amigen } \\
\text { Amigen } \\
\text { Amigen+hosp. } \\
\text { Amigen } \\
\text { Amigen } \\
\text { Gastrostomy mix. }\end{array}$ & $\begin{array}{l}\text { grams } \\
0.03 \\
0.03 \\
0.03 \\
0.03 \\
0.04 \\
0.05 \\
0.08 \\
0.09 \\
0.09 \\
0.09 \\
0.10 \\
0.10 \\
0.13 \\
0.13 \\
0.14 \\
0.14 \\
0.14 \\
0.14 \\
0.15 \\
0.15 \\
0.17 \\
0.17 \\
0.17 \\
0.18 \\
0.18 \\
0.18 \\
0.18 \\
0.19 \\
0.19 \\
0.20 \\
0.21 \\
0.22 \\
0.22 \\
0.24 \\
0.27 \\
0.27 \\
0.28 \\
0.30 \\
0.30 \\
0.30 \\
0.30 \\
0.30 \\
0.30 \\
0.30 \\
0.30 \\
0.30 \\
0.34 \\
0.39 \\
0.39 \\
0.46 \\
0.46 \\
0.47 \\
0.58 \\
0.59 \\
0.63\end{array}$ & $\begin{array}{r}2 \\
9 \\
11 \\
14 \\
20 \\
15 \\
13 \\
24 \\
9 \\
30 \\
14 \\
18 \\
19 \\
21 \\
20 \\
22 \\
22 \\
24 \\
25 \\
27 \\
19 \\
21 \\
29 \\
19 \\
21 \\
23 \\
30 \\
25 \\
22 \\
22 \\
21 \\
20 \\
31 \\
31 \\
26 \\
32 \\
31 \\
30 \\
31 \\
32 \\
33 \\
33 \\
34 \\
34 \\
36 \\
37 \\
34 \\
21 \\
32 \\
32 \\
35 \\
46 \\
16 \\
11 \\
35\end{array}$ & $\begin{array}{r}\text { grams } \\
10.8 \\
9.7 \\
8.0 \\
10.9 \\
8.5 \\
12.1 \\
28.3 \\
33.3 \\
26.7 \\
24.5 \\
36.1 \\
34.7 \\
42.0 \\
57.2 \\
41.2 \\
40.7 \\
64.0 \\
47.1 \\
46.6 \\
55.6 \\
32.1 \\
45.3 \\
34.3 \\
77.9 \\
72.5 \\
42.9 \\
50.0 \\
53.0 \\
57.1 \\
54.3 \\
91.0 \\
60.8 \\
51.0 \\
77.6 \\
78.7 \\
58.5 \\
64.5 \\
109.5 \\
87.0 \\
99.0 \\
88.2 \\
75.0 \\
59.7 \\
100.0 \\
70.5 \\
98.0 \\
73.6 \\
123.2 \\
98.8 \\
137.8 \\
117.6 \\
106.0 \\
150.6 \\
180.0 \\
160.0\end{array}$ & $\begin{array}{r}\text { grams } \\
41.1 \\
32.3 \\
45.6 \\
55.4 \\
26.7 \\
31.4 \\
69.3 \\
89.3 \\
64.5 \\
34.3 \\
69.8 \\
73.2 \\
62.3 \\
68.3 \\
64.9 \\
69.7 \\
108.3 \\
49.2 \\
45.5 \\
63.1 \\
26.4 \\
83.8 \\
33.7 \\
120.0 \\
142.7 \\
37.3 \\
57.2 \\
57.0 \\
44.6 \\
51.2 \\
114.7 \\
131.8 \\
72.2 \\
99.2 \\
56.9 \\
55.3 \\
56.2 \\
101.9 \\
68.0 \\
113.0 \\
70.1 \\
55.5 \\
74.5 \\
76.2 \\
41.1 \\
63.8 \\
41.9 \\
106.8 \\
57.5 \\
65.1 \\
102.5 \\
78.2 \\
162.6 \\
163.3 \\
105.2\end{array}$ & $\begin{array}{c}\text { grams } \\
5.0^{*} \\
4.0 \\
4.0 \\
0.7 \\
4.0 \\
3.0 \\
7.5 \\
1.5 \\
16.0 \\
5.0^{*} \\
5.0^{*} \\
5.0^{*} \\
3.5 \\
5.0^{*} \\
2.0 \\
3.5 \\
5.0^{*} \\
7.5 \\
2.0 \\
6.0 \\
5.0 \\
5.0^{*} \\
1.5 \\
5.9 \\
9.5 \\
6.0 \\
17.5 \\
7.0 \\
16.5 \ddagger \\
16.5 \ddagger \\
3.6 \\
1.7 \\
25.0 \\
5.5 \\
7.0 \dagger \\
6.2 \\
16.5 \ddagger \\
4.0 \\
14.4 \\
7.0 \dagger \\
7.0 \\
9.5 \\
0.1 \\
0.5 \\
7.5 \\
20.5 \\
8.9 \\
22.8 \\
30.0 \\
10.0 \\
9.0 \\
6.0 \\
20.0 \\
25.0 \\
25.0\end{array}$ & \begin{tabular}{|c|} 
grams \\
1.3 \\
3.7 \\
4.7 \\
0.9 \\
1.8 \\
8.3 \\
2.5 \\
0 \\
1.0 \\
0 \\
0 \\
0 \\
1.0 \\
0 \\
0.5 \\
0 \\
0.5 \\
0 \\
0 \\
0 \\
0 \\
0 \\
0.2 \\
0 \\
0 \\
1.3 \\
0.1 \\
1.3 \\
3.4 \\
6.6 \\
14.5 \\
0 \\
0.7 \\
1.4 \\
0 \\
0 \\
0 \\
0.3 \\
17.3 \\
0 \\
0 \\
4.6 \\
0.4 \\
0 \\
5.5 \\
6.8 \\
18.0 \\
7.4 \\
4.5 \\
55.5 \\
8.0 \\
0 \\
0 \\
6.5 \\
4.6
\end{tabular} & $\begin{array}{l}\text { grams } \\
0 \\
0 \\
0 \\
0 \\
0 \\
0 \\
0 \\
0 \\
0 \\
0 \\
0 \\
0 \\
0 \\
0 \\
0 \\
0.1 \\
0 \\
0 \\
0.1 \\
0 \\
0 \\
0 \\
0 \\
0 \\
0 \\
0 \\
0 \\
0 \\
0 \\
1.6 \\
0 \\
0 \\
0 \\
0 \\
1.4 \\
0 \\
0 \\
0 \\
0 \\
0 \\
0 \\
0 \\
0 \\
4.7 \\
0 \\
0 \\
0 \\
0.3 \\
0 \\
0 \\
0 \\
0.2 \\
0 \\
0 \\
0 \\
\end{array}$ & $\begin{array}{r}\text { grams } \\
47.5 \\
40.0 \\
54.3 \\
57.0 \\
32.5 \\
42.7 \\
79.3 \\
90.8 \\
81.5 \\
39.3 \\
74.8 \\
78.2 \\
66.8 \\
73.3 \\
68.9 \\
73.3 \\
113.8 \\
56.7 \\
47.6 \\
69.1 \\
31.4 \\
90.8 \\
35.4 \\
125.9 \\
152.2 \\
44.6 \\
74.8 \\
65.3 \\
64.5 \\
75.9 \\
132.8 \\
133.5 \\
97.9 \\
106.1 \\
65.3 \\
61.3 \\
72.7 \\
106.2 \\
99.7 \\
120.0 \\
77.1 \\
69.6 \\
75.0 \\
81.4 \\
54.1 \\
91.1 \\
68.8 \\
137.3 \\
92.0 \\
130.6 \\
119.5 \\
84.4 \\
182.6 \\
194.8 \\
134.8\end{array}$ & 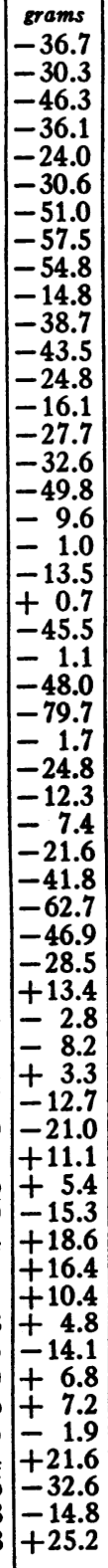 & 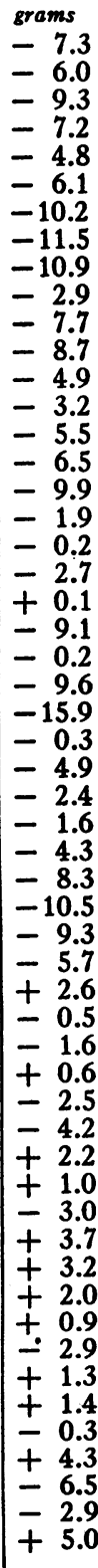 \\
\hline
\end{tabular}

* Theoretical amount of $\mathbf{5 . 0}$ grams of nitrogen added to output for 5 days for fecal nitrogen not determined. + Theoretical amount of $\mathbf{7 . 0}$ grams of nitrogen added to output for 5 days for fecal nitrogen not determined. $\$$ Theoretical amount of 16.5 grams of nitrogen added to output for 5 days for fecal nitrogen not determined. $\$$ Jejunal feeding. 
TABLE II

Fecal nitrogen

\begin{tabular}{|c|c|c|c|c|}
\hline \multirow{2}{*}{ Type of feeding } & \multirow{2}{*}{$\begin{array}{c}\text { No. of } \\
\text { patients }\end{array}$} & \multicolumn{3}{|c|}{ Daily nitrogen output } \\
\hline & & $\begin{array}{l}\text { Maxi- } \\
\text { mum }\end{array}$ & $\begin{array}{l}\text { Mini- } \\
\text { mum }\end{array}$ & Mean \\
\hline $\begin{array}{l}\text { By mouth- } \\
\text { Hospital diet }\end{array}$ & 18 & $\begin{array}{r}\text { grams } \\
1.5\end{array}$ & $\begin{array}{c}\text { grams } \\
0.1\end{array}$ & $\begin{array}{c}\text { grams } \\
1.0\end{array}$ \\
\hline $\begin{array}{l}\text { By tube into stomach- } \\
\text { Hyddrolyzed protein } \\
\text { or hydrolyzed pro- } \\
\text { tein plus hospital diet } \\
\text { By tube into jejunum- } \\
\text { Hydrolyzed protein } \\
\text { or whole protein as } \\
\text { liquid feeding }\end{array}$ & 12 & 25.0 & 0.1 & 3.3 \\
\hline
\end{tabular}

trogen in the feces, and likewise the greatest variation in fecal nitrogen excretion was found in those fed by tube, into either the stomach or jejunum. The mean figures given in Table II were used in calculating balances in the cases where fecal nitrogen was not actually determined. The mean values for excretion of fecal nitrogen when food is given by mouth or by tube into the stomach agree with those given by Reifenstein, Albright and Wells (9).

\section{Plasma proteins.}

Because of the close relationship between hypoproteinemia and certain postoperative surgical complications (10 to 12 ), we were interested in studying the plasma protein concentration of surgical patients on various dietary regimes, but found that there was no significant correlation between the food intake and changes in plasma protein concentration, nor between nitrogen balance and changes in plasma protein concentration in this series of patients.

\section{DISCUSSION}

From the results obtained, it is apparent that surgical patients after operation require a larger intake of nitrogen to maintain positive nitrogen balance than has been recommended for normal individuals. Sherman (13) gives figures of 0.1 gram of nitrogen per kgm., and approximately 35 calories per $\mathrm{kgm}$. for 1 normal individual. Rose and MacLeod (14) in a study of 4 normal active women found that $0.5 \mathrm{gram}$ of protein $(0.08 \mathrm{gram}$ of nitrogen), and approximately 40 calories per kgm. daily, were sufficient. Mueller, Fickas and Cox (15), using an Amigen supplement to a basal diet, were able to produce considerable diminution in the amount of negative nitrogen balance in 4 normal men, and even to get positive balance in 2, giving 0.1 gram of nitrogen per $\mathrm{kgm}$., and 26 to 28 calories per $\mathrm{kgm}$. daily. The only nitrogen figures for normal individuals which approach the level found necessary by us for the immediate postoperative period are the amounts recommended by Howe (16) or the United States Army (men on moderate activity), 107.0 grams of protein and approximately 3,500 calories (for a $65 \mathrm{kgm}$. person this is 0.26 gram of nitrogen per kgm., and 53 calories per kgm. daily).

The increased nitrogen loss following trauma has been extensively studied in fractures of long bones $(2,3)$ and in burns $(17,18)$. Similar data for patients undergoing other types of surgical treatment, such as gastric or cranial operations, are meager. Ariel and his associates (19) have reported hypoproteinemia following operation for cancer of the gastro-intestinal tract. Elman (20) has frequently written of the poor state of nutrition of surgical patients, and reported on the use of hydrolyzed casein intravenously in the correction of hypoproteinemia in patients undergoing surgical operation. Mulholland, Co Tui et al (21) described the results obtained in 4 carefully studied postoperative gastric cases who received hydrolyzed casein as the source of nitrogen, together with 4 controls. Co Tui, Wright, Mulholland et al (22) reported studies on 19 postgastrectomy cases, of whom 8 on a high nitrogen, high caloric intake were in positive nitrogen balance. Brunschwig (23), in a series of 41 patients undergoing various types of operation, found that negative nitrogen balances were present in the majority of them. The dietary regimen of Brunschwig's patients was similar to that of many of our patients (Table II) and is the common one of intravenous fluids (usually saline or glucose solutions) followed by liquids by mouth on the third or fourth postoperative day, and soft to regular ward diet thereafter.

From these previously reported studies, it is not possible to determine the minimum level of nitrogen intake required to maintain the patient in nitrogen equilibrium. In our series 0.30 gram of nitrogen and 30 calories per $\mathrm{kgm}$. daily proved to 
be a level at which we could expect to have most patients in positive nitrogen balance in the early postoperative period. The relation between nitrogen intake and total calories was, in part, arbitrary. We recognize that it may have been possible to decrease the nitrogen level with a concurrent increase in caloric intake and still keep the patient in nitrogen equilibrium. While nitrogen intake has probably been more neglected in the management of surgical patients than caloric intake, the latter must not be allowed to fall too low. This is borne out by the data in Table I from 2 patients who had high nitrogen but low caloric intakes. It is interesting to note that in the cases reported by other workers $(21,22)$, where calculations can be made, and where the period of study is the same in relation to day of operation as in our studies, the amounts of nitrogen and the total calories with which they achieved positive nitrogen balance were well above the minimum effective level found in our studies.

It is clear from Table I that there are marked individual differences in the nitrogen excretion of patients on about the same nitrogen and caloric intake. Undoubtedly this is affected by anesthesia, the extent of operation, the degree of trauma, the previous nutritional history of the patient, the degree of postoperative pyrexia and many other factors. It, however, seemed useful to determine approximately the amount of food required to keep the majority of patients in balance after gastric and intracranial operations.

A criterion frequently used as a measure of the effectiveness of procedures intended to correct protein deficiencies in surgical patients is the concentration of plasma or serum protein. Our results indicate that plasma protein concentration may be misleading as an index of whether or not the patient is overcoming excessive nitrogen loss. In some instances, although the concentrations (corrected for change in hematocrit) were increased, the patients were in negative nitrogen balance.

In this study, hydrolyzed protein was found to be just as effective as whole protein in maintaining nitrogen balance.

A real difficulty in the forced feeding of patients in the early postoperative period is the frequency with which vomiting, diarrhea or distention follows such a program. Usually it was possible to overcome these obstacles by symptomatic treatment, but occasionally it was necessary to abandon the intended regimen. It is quite possible that intravenous feeding, rather than mouth feeding, may have a place of special importance in maintaining the nutrition of the patient in the first 48 to 72 hours after operation.

It should be emphasized that this study is concerned mainly with types of patients which are apt to present nutritional problems before and after operation. It is recognized that such patients represent a small minority of all general surgical patients, and it is not the intention of the authors to suggest that the forced feeding methods described are indicated for the majority of surgical patients.

\section{CONCLUSIONS}

1. Surgical patients after gastric or cranial operations were usually in negative nitrogen balance for the first 5 postoperative days on the dietary regimen customarily followed in this clinic.

2. Surgical patients undergoing gastric or cranial operations require a greater intake of dietary nitrogen and of total calories than do normal individuals to keep them in nitrogen equilibrium for the first 5 postoperative days.

3. By increasing the nitrogen intake to $0.30 \mathrm{gram}$ per kgm., and the caloric intake to 30 calories per $\mathrm{kgm}$. daily, or over, patients fed by mouth or Abbott-Rawson tube were usually maintained in nitrogen equilibrium.

4. Hydrolyzed protein in the form of a casein hydrolysate, combined with carbohydrate, was equally as effective as whole protein when administered by the same routes.

5. The variations in fecal nitrogen were large, and they are an important part of the nitrogen balance study of patients in the early postoperative period, especially when tube feedings are used.

6. The plasma or serum protein concentrations were not an accurate index of the effect of a nutritional regimen on nitrogen equilibrium in postoperative patients.

\section{BIBLIOGRAPHY}

1. Lund, C. C., and Levenson, S. M., Protein in surgery. J. A. M. A., 1945, 128, 95.

2. Cuthbertson, D. P., Further observations on the disturbance of metabolism caused by injury, with par- 
ticular reference to the dietary requirements of fracture cases. Brit. J. Surg., 1935-1936, 23, 505.

3. Howard, J. E., Parson, W., Stein, K. E., Eisenberg, H., and Reidt, E. V., Studies on fracture convalescence; nitrogen metabolism after fracture and skeletal operations in healthy males. Bull. Johns Hopkins Hosp., 1944, 75, 156.

4. Stengel, A., Jr., and Ravdin, I. S., Maintenance of nutrition in surgical patients, with description of orojejunal method of feeding. Surgery, 1939, 6, 511.

5. Bisgard, J., Gastrostomy. Jejunal intubation. Surg., Gynec. and Obst., 1942, 74, 239.'

6a. Chibnall, A: C., Rees, M. W., and Williams, E. F., Total nitrogen content of egg albumin and other proteins. Biochem. J., 1943, 37, 354.

6b. Meeker, E. W.; and Wagner, E. C., Titration of ammonia in presence of boric acid. J. Ind. Eng. Chem. Anal. Ed., 1933, 5, 396. 1940, 12, 771.

7. Koch, F. C., and McMeekin, T. L., A new direct nesslerization micro Kjeldahl method and a modification of the Nessler-Folin reagent for ammonia. J. Am. Chem. Soc., 1924, 46, 2066.

8a. Sherman, H. C., and Lanford, C. S., Essentials of Nutrition. Macmillan Co.

8b. Cooper, L. F., Barbour, E. M., and Mitchell, A. F., Nutrition in Health and Disease. J. B. Lippincott Co.

9. Reifenstein, E. C., Jr., Albright, F., and Wells, S. L., Accumulation, interpretation and presentation of data pertaining to metabolic balances, notably those of calcium, phosphorus, and nitrogen. J. Clin. Endocrinol., 1945, 5, 367.

10. Jones, C. M., and Eaton, F. B., Postoperative nutritional edema. Arch. Surg., 1933, 27, 159.

11. Mecray, P. M., Barden, R. P., and Ravdin, I. S., Nutritional edema. Its effect on gastric emptying time before and after gastric operations. Surgery, 1937, 1, 53.

12. Thompson, W. C., Ravdin, I. S., and Frank, I. L., Effect of hypoproteinemia on wound disruption. Arch. Surg., 1938, 36, 500.

13. Sherman, H. C., Gillett, L. H., and Osterberg, E., Protein requirement of maintenance in man and the nutritive efficiency of bread protein. J. Biol. Chem., 1920, 41, 97.

14. Rose, M. S., and Macleod, G., Maintenance values for proteins of milk, meat, bread and milk, and soy bean curd. J. Biol. Chem., 1925, 66, 847.

15. Mueller, A. J., Fickas, D., and Cox, W. M., Minimum maintenance requirement of an enzymic casein hydrolysate. Bull. Johns Hopkins Hosp., 1943, 72, 110.

16. Howe, P. E., Nutrition as it affects military personnel. Med. Clin. North America, 1943, 27, 581.

17. Taylor, F. H. L., Levenson, S. M., Davidson, C. S., Browder, N. C., and Lund, C. C., Problems of protein nutrition in burned patients. Ann. Surg., 1943, 118, 215.

18. Hirshfeld, J. W., Abbott, W. E., Pilling, M. A., Heller, C. G., Meyer, F., Williams, H. H., Richards, A. J., and Obi, R., Metabolic alterations following thermal burns. III. Effect of variations in food intake on nitrogen balance of burned patients. Arch. Surg., 1945, 50, 194.

19. Ariel, I., Abels, J. C., Pack, G. T., and Rhoads, C. P., Postoperative hypoproteinemia and relationship of serum protein fall to urinary nitrogen excretion. Surg., Gynec. and Obst., 1943, 77, 16.

20. Elman, R., Oral use of amino acids of hydrolysed casein in surgical patients. Am. J. Digest. Dis., 1943, 10, 48.

21. Mulholland, J. H., Co Tui, F. W., Wright, A. M., and Vinci, V. J., Nitrogen metabolism, caloric intake, and weight loss in postoperative convalescence. A study of eight patients undergoing partial gastrectomy for duodenal ulcers. Ann. Surg., 1943, 117, 512.

22. Co Tui, F. W., Wright, A. M., Mulholland, J. H., Carabba, V., Barcham, I., and Vinci, V. J., Studies on surgical convalescence. I. Sources of nitrogen loss postgastrectomy and effect of high amino acid and high caloric intake on convalescence. Ann. Surg., 1944, 120, 99.

23. Brunschwig, A., Clark, D. E., and Corbin, N., Postoperative nitrogen loss and studies on parenteral nitrogen nutrition by means of casein digest. Ann. Surg., 1942, 115, 1091. 